\title{
RELAPSE OF PLEOMORPHIC ADENOMA FROM CHILDHOOD TO ADULTHOOD: CASE REPORT
}

\author{
Stjepan Grabovac ${ }^{1}$, Đurđica Grabovac ${ }^{2}$, Zrinka Puharić ${ }^{2}$ and Vesna Malčić Dalipi ${ }^{1}$ \\ ${ }^{1}$ Bjelovar General Hospital, Department of Otorhinolaryngology, Bjelovar, Croatia; \\ ${ }^{2}$ High Nursing College, Bjelovar High Technical School, Bjelovar, Croatia
}

\begin{abstract}
SUMMARY - Pleomorphic adenoma is rarely seen in childhood. After detailed literature search, we did not come across a case of frequent relapse of this benign tumor from childhood to adulthood. The World Health Organization defines relapse of pleomorphic adenoma as a histologically benign tumor that can have local or distant metastasis. There is one hypothesis how benign tumor can metastasize. According to this hypothesis, probably during the first operative procedure the tissue around the tumor becomes permeable for tumor cells, which can lead to implantation of tumor cells into the surrounding tissue. In this case report, we present a case of a 30-year-old woman with pleomorphic adenoma of the submandibular gland, which relapsed three times. The patient was first operated on in 1993, at the age of 7 years. The first two relapses occurred in 1998 and 2001, at the age of 12 and 15, respectively. The last relapse occurred in 2015 , at the age of 29 years. All relapses were localized in the submandibular region on the right side of the neck, where the primary tumor had been operated on.
\end{abstract}

Key words: Adenoma, pleomorphic; Submandibular gland; Neoplasm recurrence, local

\section{Introduction}

Tumors of salivary glands account for $1 \%-4 \%$ of all neoplastic tumors in humans. These tumors are very rare in childhood but $35 \%$ of them are malignant. The most frequently seen tumor of salivary glands is pleomorphic adenoma that generally has an abundant amount of connective tissue and is therefore also named mixed tumor.

These tumors are classified as semi-malignant to make clinicians aware of their potential malignant behavior. Their multilocular structure, with fingerlike elongations, is a reason for possible tumor penetration into the surrounding tissue ${ }^{1-4}$.

The other group of tumors of salivary glands is metastatic pleomorphic adenoma (MPA) that, up to day, is still an unsolved entity. It is a histologically be-

Correspondence to: Stjepan Grabovac, $M D, P h D$, Department of Otorhinolaryngology, Bjelovar General Hospital, Mihanovićeva 8, HR-43000 Bjelovar, Croatia

E-mail: stjepan.grabovac@obbj.hr

Received June 14, 2016, accepted February 8, 2017 nign tumor which may give local and distant metastasis. The most frequent site of MPA is parotid gland (74\%), then small salivary glands (16\%) and submandibular gland (10\%). In the history of the disease, the majority of patients (81\%) have at least one relapse before encountering distant metastasis. Bones are most frequently involved with metastasis (45\%), followed by lungs (36\%) and internal organs (10\%). In the head and neck region, lymph nodes may be affected in $17 \%$ of cases. After the initial treatment of benign pleomorphic adenoma, MPA develops in 5 years on average, although metastases have been described 16, 30, or even 50 years after the first operation. According to some authors, the rate of 5 -year disease-free period for MPA is $58 \%$,

Nowadays, it is not possible to predict which benign pleomorphic adenoma has metastatic potential. The use of positron emission tomography (PET) scan to define distant metastasis or immunohistologic analysis used to predict the possible occurrence of metastasis did not yield relevant clinical data due to the small number of patients ${ }^{5-8}$. For this reason, MPA is still 
considered as a consequence of inadequate first operation. When enucleation of the tumor was the preferred surgical approach, relapses were diagnosed in $20 \%$ $45 \%$ of cases ${ }^{9}$.

Adjuvant radiotherapy and chemotherapy as preventive measures for possible relapse of the disease did not prove successful, and surgical treatment remains the first option in the treatment of MPA ${ }^{10}$.

The paradoxical nature of MPA with its benign histologic characteristics and ability to give metastasis

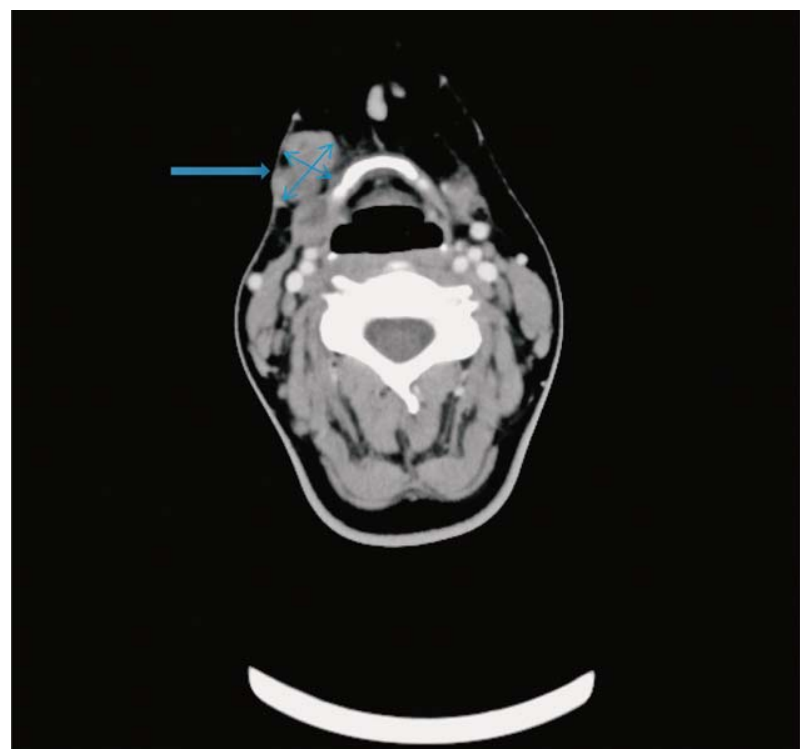

Fig. 1. Multi-slice computed tomography scan of the neck; arrow indicating numerous nodose shades, $0.9-1.4 \mathrm{~cm}$ in diameter, in the right submandibular region.

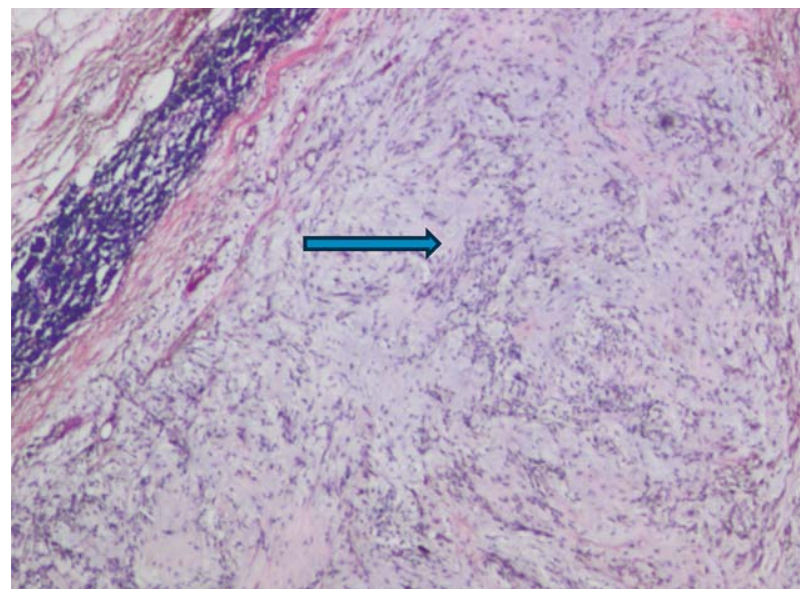

Fig. 2. Salivary gland tissue with few nodular tumorous sites; arrow indicating nodular tumorous sites (HE, X100). intrigues clinicians all over the world. There are few hypotheses why a benign tumor may give metastasis. One of them is the implantation hypothesis according to which blood and lymph vessels become permeable for tumor cells, which then enter the surrounding tissue. However, metastasis of pleomorphic adenoma found in bones and internal organs, without a history of previous operation of salivary glands beat the implantation theory. Distant metastases are explained by the ability of MPA to mutate the previously accumulated genetic potential. Current diagnostic methods cannot classify pleomorphic adenoma or identify which benign pleomorphic adenoma has a metastatic potential. Good patient history is the basis to suspect relapse in a patient who was treated for pleomorphic adenoma ${ }^{11-13}$.

\section{Case Report}

In this case report, we present a 30-year-old woman who had 3 relapses of pleomorphic adenoma. In 1993, at the age of 7 years, pleomorphic adenoma of the right submandibular gland was diagnosed. Extirpation of the whole gland with the tumor was performed. Histopathologic report revealed pleomorphic adenoma, which was removed completely. The first relapse occurred in 1998, i.e. 5 years after the first operation, in the region of surgical scar, where a nodule of $1 \mathrm{~cm}$ in size appeared. Cytologic report revealed pleomorphic adenoma. Selective supraomohyoid dissection of the neck was per-

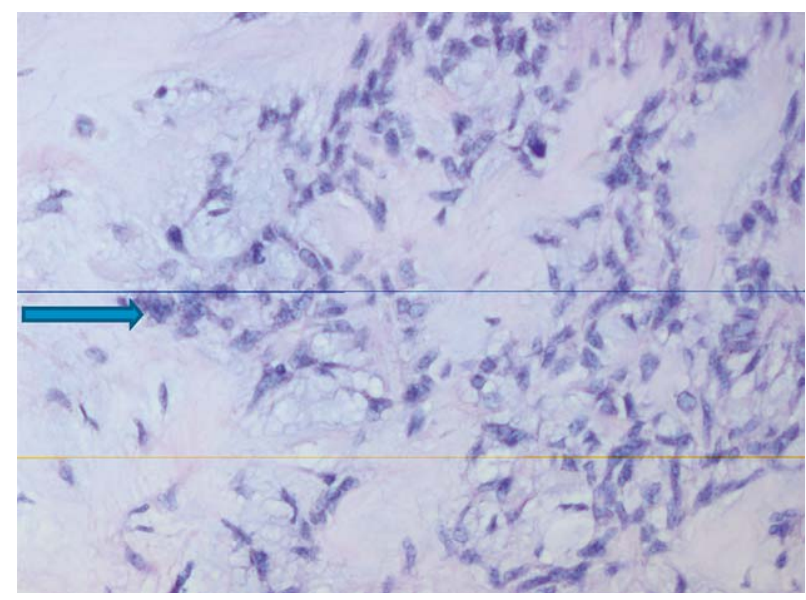

Fig. 3. Salivary gland tissue with few nodular timorous sites; arrow indicating tumorous cells within nodular tumorous sites (HE, X200). 
formed. Histologic examination confirmed the nodule to be pleomorphic adenoma.

The second relapse occurred in 2001. At $1 \mathrm{~cm}$ deep to the incisional scar from the previous surgical procedure, a single subcutaneous nodule was found. In the neck region I and II, excision of the scar and surrounding tissue including the subcutaneous nodule was performed. Histologic examination confirmed the nodule to be pleomorphic adenoma. During the next 5 years, the patient was regularly followed-up. Besides ultrasonographic examination of the neck, abdominal organs were also examined by ultrasound.

The third relapse occurred in 2012. The patient noticed a new nodule in the scar but came to the hospital three years later, in 2015. In the region of the scar, a few nodules were present, all of them solid in consistency and partially fixed. The biggest nodule was 1.5 $\mathrm{cm}$ in diameter. Contrast computed tomography (CT) of the neck region revealed a few inhomogeneous nodules, $0.9-1.4 \mathrm{~cm}$ in diameter, in the right submandibular region (Fig. 1).

Cytological puncture confirmed the metastasis of pleomorphic adenoma. Including the scars, wide reexcision of the neck region I and II was performed. Macroscopically, four oval, well-formed, white nodules were found in the subcutaneous tissue. The size of the biggest nodule was $2.5 \mathrm{~cm}$ in diameter. Histologic examination confirmed pleomorphic adenoma in all four nodules (Figs. 2 and 3). Ultrasound examination of the abdominal organs and $\mathrm{x}$-ray of the lungs were normal.

\section{Discussion}

Pleomorphic adenoma with metastasis is a rare clinical entity, characterized by the presence of one or more histologically benign tumors outside the salivary gland. In the majority of cases, metastases are reported in patients that were previously operated on due to pleomorphic adenoma $a^{5-7}$. Good patient history is inevitable to suspect the possible metastases related to pleomorphic adenoma. The first relapse can be explained by the surgical method used. As mentioned before, in cases of macroscopically well-defined tumors, enuclation was the surgical procedure of choice'.

Finger-like extensions of pleomorphic adenoma, which are not removed during surgical procedure, are the most probable reason for relapse. As surgical techniques have improved, enuclation technique has been replaced with superficial parotidectomy as a minimal surgical approach in removing pleomorphic adeno$\mathrm{ma}^{15-17}$.

During superficial parotidectomy as a surgical treatment of pleomorphic adenoma relapse, the tumor must be removed according to the accepted oncologic principles. Even then, the risk of relapse of the tumor cannot be excluded. It is explained by the hypothesis according to which substances excreted by the tumor can increase permeability of the surrounding blood and lymph vessels. During surgical procedure, manipulation of the tumor tissue may cause tumor cells to enter the blood and lymph vessels ${ }^{5-8}$.

This hypothesis could explain the occurrence of 1ocal, as well as distant metastasis of this tumor that is benign in nature. In spite of this logical explanation, there are reports of patients where metastases of pleomorphic adenoma were found in bones and/or internal organs, although primary tumor had not been operated on or was found after encountering metastases. These cases were explained by the hypothesis according to which pleomorphic adenoma could genetically mutate its genetic potential ${ }^{11-14}$.

Current diagnostic methods cannot predict/define which benign pleomorphic adenoma shows aggressive component that can lead to development of metastasis. Numerous immunohistologic techniques have been used in an attempt to solve the unpredictable nature of pleomorphic adenoma, e.g., Ki-67, p53, p16, bci-2. These immunohistologic techniques are highly immune reactive in cases of malignant tumors of salivary glands ${ }^{18-21}$.

Due to the small number of tissue specimens taken, immunohistologic analysis done in order to predict the possible malignant nature of pleomorphic adenoma did not give satisfactory results. Therefore, results of this procedure should be taken with caution. Analysis of a greater number of specimens may help understand the biological mechanisms and genetic mutations that take part in the malignant nature of benign pleomorphic adenoma. In spite of the achievements in modern medicine, patient history remains a mainstay in the diagnosis of $\mathrm{MPA}^{22,23}$.

It is an open question whether to tell the patient, especially children and their parents, about the unpredictable nature of the tumor or to tell about it when the relapse occurs. Is it necessary to make the patient live with this fear for life? How long should the patient be followed-up? 
Although in our practice we had just one patient with MPA, we find it worth mentioning since it was a case of a child that had to grow up with that disease. Nowadays, the majority of patients are very well selfinformed about their disease; subsequently, according to our opinion, there is no need to tell the patient with benign pleomorphic adenoma about the possible relapses, which are anyhow difficult to predict. The patient should be informed about the nature of pleomorphic adenoma in case of proved relapse. The benign nature of the disease should be pointed out. Further, it is difficult to define the time-line for follow up checkups since relapse can occur many years after the first surgery. Individual approach to the patient, as well as patient age and location of relapse should be taken in consideration.

\section{Conclusion}

In childhood, the occurrence of pleomorphic adenoma is rare and relapses are really unique cases. Here, we present a case of pleomorphic adenoma of the submandibular gland that relapsed three times over 18 years of the initial diagnosis. Except for good patient history, to date there is no proved medical approach to predict the possible relapse and its prevention. In the case of relapse of pleomorphic adenoma, the treatment of choice is surgery. The nature of the disease brings a dilemma whether to warn the patient about the possibility of the disease relapse or the patient should be told that he/she is completely cured.

According to our opinion, in such cases, the approach to the patient should be individualized. The unpredictable nature of pleomorphic adenoma and the possibility of relapse should only be explained to patients that experience relapse of the disease.

\section{References}

1. Oh YS, Eisele DW. Salivary gland neoplasm. In: Bailey BJ, Johnson JT, Newlands SD, editors. Head and Neck Surgery Otorhinolaryngology. $4^{\text {th }}$ edn. Vol. 1. Philadelphia, PA, USA: Lippincott Williams \& Wikins 2006; p. 1515-6.

2. Alves FA, Perez DEC, Almeida OP, Lopes MA, Kowalski LP. Pleomorphic adenoma of the submandibular gland: clinicopathological and immunohistochemical features of 60 cases in Brazil. Arch Otolaryngol. 2002;128:1400-3. https:/www.ncbi.nlm.nih.gov/pmc/articles/PMC4119378/

3. Becerril-Ramirez PB, Bravo-Escobar GA, Prado-Calleros HM, Castillo-Ventura BB, Pombo-Nava A. Histology of sub- mandibular gland tumours, 10 year experience. Acta Otorrinolaringol Esp. 2011;62:432-5.

https://www.ncbi.nlm.nih.gov/pmc/articles/PMC4119378

4. Enescu AS, Enescu A, Balasoiu M, Ciolofan MS, Capitanescu AN. Histopathological study of pleomorphic adenoma of salivary glands. Rom J Morphol Embryol. 2014;55:1149-53. www.asianpharmtech.com/download.php?..

5. Papadogeorgakis N, Kalfarentzos EF, Petsinis V, Parara E, Kopaka ME. Multinodular neck recurrence of parotid gland pleomorphic adenoma: a case report. Oral Maxillofac Surg. 2012;16: 137-40. https://www.ncbi.nlm.nih.gov/pubmed/21660435

6. Miladi S, Mestiri S, Kermani W, Ziadi S, Sriha B, Bouzouita K, Mokni M. Metastasizing pleomorphic adenoma of the submandibular gland: a case report. Pathologica. 2014;104:29-31. europepmc.org/abstract/med/24897779

7. Rodriguez Fernandez J, Metos Micas M, Martinez Tell FJ. Metastatic benign pleomorphic adenoma. Report of case and review of the literature. Med Oral Patol Oral Cirurg Bucal. 2008;13:193-6.

8. Nouraei SAR, Ferguson MS, Clarke PM. Metastasizing pleomorphic salivary adenoma. Arch Otolaryngol. 2006;132: 788-93. journals.cambridge.org/abstract_S0022215107000345

9. Conley JJ. Concept in Head and Neck Surgery. New York, USA: Grune and Stratton; 1970.

10. Jardel P, Fakhry N, Makeieff M, Ferrie JC, Milin S, Righini C, Lacout A, Costes V, Malard O, Marcy PY, Guevara N, Odin G, Bensadoun RJ, Thariat J. Radiation therapy for pleomorphic adenoma of the parotid. Cancer Radiother. 2014;18:68-76. https://www.ncbi.nlm.nih.gov/pubmed/24387927

11. Singhal A, Shrago SS, Li SF. A hepatic metastasis from pleomorphic adenoma of salivary gland: an unusual presentation. Hepatogastroenterology. 2010;57:330-3.

12. Vivian MA, Sahni VA, Lowe AC. Benign metastasizing pleomorphic adenoma presenting as a solitary kidney mass: imaging features. Urology. 2012;80:17-8.

13. Czader M, Eberhart CG, Bhatti N, Cummings C, Westra WH. Metastasizing mixed tumor of the parotid: initial presentation as a solitary kidney tumor and ultimate carcinomatous transformation at the primary site. Am J Surg Pathol. 2000; 24:1159-64.

14. Fujimura M, Sugawara T, Seki H. Carcinomatous change in the cranial metastasizing mixed tumor of the salivary gland. Neurol Med Chirurg. 1997;37:546-50.

15. Zbaren P, Vander Poorten V,Witt RL, Woolgar JA, Shaha AR, Triantafyllou A, Takes RP, Rinaldo A, Ferlito A. Pleomorphic adenoma of the parotid: formal parotidectomy or limited surgery? Am J Surg. 2013;1:109-18.

16. Dell Aversana Orabona G, Bonavolonata P, Laconetta G, Forte R, Califano L. Surgical management of benign tumors of the parotid gland: extracapsular dissection versus superficial parotidectomy - our experience in 232 cases. J Oral Maxillofac Surg. 2013;71:410-3.

17. Fukushima M, Miyaguchi M, Kitahara T. Extracapsular dissection: minimally invasive surgery applied to patients with $\mathrm{pa}^{-}$ 
rotid pleomorphic adenoma. Acta Otolaryngol. 2011;131: 653-9. https://www.researchgate.net/.../261519498

18. Luukkaa H, Klemi P, Leivo I, Vahlberg T, Grenman R. Prognostic significance of $\mathrm{Ki}-67$ and $\mathrm{p}-53$ as tumor markers in salivary gland malignancies in Finland: an evaluation of 212 cases. Acta Oncol. 2006; 45:669-75.

www.tandfonline.com/doi/full/10.1080/02841860500543208

19. Hu YH, Zhang CY, Tian Z, Wang LZ, Li J. Aberrant protein expression and promoter methylation of p16 gene are correlated with malignant transformation of the pleomorphic adenoma. Arch Pathol Lab Med. 2011;135:882-9.

20. Freitas LL, Araujo VC, Martins MT, Chone C, Crespo A, Altemani A. Biomarker analysis in carcinoma ex pleomorphic adenoma at an early phase of carcinomatous transformation. Int J Surg Pathol. 2005;13:337-42.
21. Aoki T, Tsukinoki K, Karada K, Ota Y, Otsuru M, Kaneko A. Expression of cyclooxygenase-2, Bcl-2 and $\mathrm{Ki}-67$ in pleomorphic adenoma with special reference to tumor proliferation and apoptosis. Oral Oncol. 2004;40:954-9.

https:/www.ncbi.nlm.nih.gov/pubmed/15380175

22. Skalova A, Altemani A, Di Palma S, Simpson RH, Hosticka L, Andrie P, Laco J, Toner M, Vozmitsel MA, Szakacs S, Kazakov DV, Kinkor Z, Michal M. Pleomorphic adenoma of the salivary glands with intravascular tumor deposits: a diagnostic pitfall. Am J Surg Pathol. 2012;36:1674-82.

23. Nikolić N, Aničić B, Tepavčević Z, Jezdić Z, Čarkić J, Toljić B, Dedović-Tanić N, Konstantinović V, Vukadinović M, Milašin J. Somatic mutation and polymorphism analysis in pleomorphic adenomas of the salivary glands. J Med Biochem. 2013;32:354-60. https://www.degruyter.com/view/j/jomb.../ jomb-2013-0048.xml

Sažetak

\section{RECIDIV PLEOMORFNOG ADENOMA OD DJEČJE DO ODRASLE DOBI: PRIKAZ SLUČAJA}

\section{S. Grabovac, Đ. Grabovac, Z. Pubarići V. Malčić Dalipi}

Pleomorfni adenom u dječjoj dobi je rijedak. Pojavu višekratnih recidiva, inače dobroćudnog tumora, od dječje do odrasle dobi nismo našli opisanu u svjetskoj literaturi. Svjetska zdravstvena organizacija definira recidiv pleomorfnog adenoma kao histološki dobroćudan tumor koji može dati lokalne ili udaljene metastaze. Jedna od hipoteza zašto histološki dobroćudan tumor daje metastaze je da pri prvoj operaciji okolno tkivo postane propusno za tumorske stanice, pri čemu dolazi do implantacije tumora u okolno tkivo. U radu smo opisali slučaj 30-godišnje žene kod koje je pleomorfni adenom submandibularne žlijezde slinovnice recidivirao tri puta. Prvi puta je operirana 1993. u dobi od 7 godina. Recidivi tumora javili su se 1998. i 2001. u dobi od 12 i 15 godina. Posljednji recidiv javio se 2015. godine kada je imala 29 godina. Svi recidivi bili su u submandibularnoj regiji desne strane vrata gdje je bio operiran primarni tumor submandibularne žlijezde slinovnice.

Ključne riječi: Adenom, pleomorfni; Submandibularna žlijezda; Tumor, recidiv, lokalni 